\title{
DEVELOPMENT AND DRY MASS ACCUMULATION IN CALLA LILY AT THE INITIAL CULTIVATION STAGE
}

\author{
Desenvolvimento e acúmulo de massa seca em copo-de-leite em fase inicial de cultivo
}

\author{
Daniella Nogueira Moraes Carneiro' , Elka Fabiana Aparecida Almeida ${ }^{2}$, Patrícia Duarte de Oliveira Paiva ${ }^{3}$, \\ Jussara Ellen Morais Frazão ${ }^{4}$, Fernanda Helena de Souza Santos ${ }^{3}$, Leandro Flávio Carneiro ${ }^{5}$
}

\begin{abstract}
The cultivation of the calla lily, despite its importance in the floriculture sector, is still limited due to the lack of knowledge of basic production techniques such as development and dry mass accumulation. These techniques facilitate more appropriate management, especially regarding the application of fertilizers, providing better nutrients utilization and greater yields. Thus, this study was aimed at evaluating the growth and development of calla lily plants, establishing growth curves according to dry mass accumulation. Acclimatized and micropropagated calla lily plantlets were grown in plastic pots containing coconut fiber as a substrate and fertilized with a modified formula of Malavolta. Treatments consisted of assessments at intervals of 30 days for 7 months. The design was in randomized blocks with four replications, in a total of 28 plots. Plants were evaluated by observing their growth characteristics and development of shoots, rhizome, roots, as well as production and flower quality. Development of the plants increased throughout the experimental period, with the maximum dry mass accumulation occurring at the end of the experimental period. Blooming was constant with the length of flower stalks increasing with along with the age of the plant.
\end{abstract}

Index terms: Zantedeschia aethiopica, floriculture, growth, production.

\section{RESUMO}

O cultivo de Zantedeschia aethiopica, apesar de sua importância no segmento da floricultura, ainda é limitado pelo reduzido conhecimento em técnicas básicas de produção, como o desenvolvimento e acúmulo de massa seca. Essas informações permitem um manejo mais adequado, sobretudo referente à aplicação de fertilizantes, proporcionando melhor aproveitamento de nutrientes e maiores produções. Dessa forma, neste estudo, objetivou-se avaliar o crescimento e desenvolvimento de plantas de copo-de-leite, estabelecendo curvas de crescimento, considerando o acúmulo de massa seca. Para tanto, mudas micropropagadas e aclimatizadas de copo-de-leite foram cultivadas em vasos plásticos contendo como substrato fibra de coco e adubadas com a formulação modificada de Malavolta. Foram realizadas avaliações com intervalos de 30 dias, durante 7 meses, nos quais consistiram os tratamentos. O delineamento utilizado foi em blocos casualizados, com 4 repetições, totalizando 28 parcelas. As plantas foram avaliadas quanto às características de crescimento e desenvolvimento da parte aérea, rizoma, raízes, além de produção e qualidade das inflorescências. O desenvolvimento das plantas de copo-de-leite foi crescente ao longo do período experimental, sendo que o máximo acúmulo de massa seca total ocorreu ao final do período analisado. O florescimento foi constante com aumento do comprimento das hastes florais proporcional à idade das plantas.

Termos para indexação: Zantedeschia aethiopica, floricultura, crescimento, produção.

(Received in april 24, 2010 and approved in november 11, 2010)

\section{INTRODUCTION}

Calla lily (Zantedeschia aethiopica) is a perennial plant grown for the production of cut flowers, especially for decorative uses. It is grown mainly in Southeastern Brazil, making the region very important to the industry (ALMEIDA; PAIVA, 2005, LANDGRAF; PAIVA, 2009a, LANDGRAF; PAIVA, 2009b).

In Brazil, information about growth throughout the production cycle for the calla lily culture is still lacking. Calla lily producers perform management empirically, without precise recommendations about fertilization requirements (ALMEIDA; PAIVA, 2005). The determination for the adequate supply of nutrients at each culture development stage is based on the study of growth curves and dry mass accumulation, which highlight periods and absorption rates of nutrients by plants, providing basic information about their nutritional needs (PEDROSA, 2000; MALAVOLTA, 2006, VIEIRA et al., 2008).

\footnotetext{
${ }^{1}$ Universidade Federal de Lavras/UFLA - Departamento de Agricultura/DAG - Cx. P. 3037-37200-000 - Lavras - MG - Brasil - daninog27@yahoo.com.br Empresa de Pesquisa Agropecuária de Minas Gerais/EPAMIG - São João del Rei - MG - Brasil

3Universidade Federal de Lavras/UFLA - Departamento de Agricultura/DAG - Lavras - MG - Brasil

${ }^{4}$ Universidade Federal da Paraíba/UFPB - Centro de Ciências Humanas, Sociais e Agrárias/CCHSA - Bananeiras - PB - Brasil

5Universidade Estadual de Mato Grosso do Sul/UEMS - Cassilândia - MS - Brasil
} 
Researches on growth curves and dry mass accumulation has already been performed for other ornamental species such as Lilium spp (ORTEGA et al., 2006), Rosa spp (CABRERA, 2002), Tulipa gesneriana L. (VARGAS; TEIJOS, 2008) and Anthurium andreanum Linden (DUFOUR; GÉRIN, 2005).

Considering the need of information about this culture and its economic importance, the aim of this study was to evaluate the development of calla lily plants at the initial cultivation stage, establishing growth curves for dry mass accumulation.

\section{MATERIAL AND METHODS}

Micropropagated and acclimatized calla lily plantlets were placed in plastic trays containing Plantmax ${ }^{\circledR}$ substrate, and incubated under intermittent mist during 60 days. When they reached an average of $48 \mathrm{~cm}$, the plantlets were removed from the substrate and the roots were washed in water. The plantlets were then transplanted to pots with $8 \mathrm{dm}-3$ with granular coconut fiber Golden Mix ${ }^{\circledR}$ substrate PM-11 (Amafibra ${ }^{\circledR}$ ), consisting of the following nutrients, in $\mathrm{mg} \mathrm{dm}-3: \mathrm{N}-140$; P2O5-160; K2O-180; Ca-256; Mg-39; S-93; B-2.3; Cu-9.8; Fe-28.5; Mn-6.6; Mo-4.0; Zn-9.0.

Plants were grown under $80 \%$ shade provided by a Sombrite ${ }^{\circledR}$ shade screen placed within a greenhouse. The substrate humidity was controlled daily and manual irrigation was performed with a water volume according to plant growth and environmental conditions throughout the experiment.

Fertilization was performed every 30 days, using the formulation of Malavolta and Muraoka (1985) with modifications, by providing in $\mathrm{mg} \mathrm{dm}^{-3}: \mathrm{N}-300 ; \mathrm{P}-120$; K90; Ca-269,67; Mg-25; S-25; B-0.3; Cu-1.3; Fe-5.0; Mn-1.25; Mo-0.1 and Zn-1.87. Macronutrient fertilization was divided over 7 times, all applied through nutrient solution. Micronutrients were applied in a single dosage in the first fertilization, conducted immediately after the seedlings were transplanted.

The treatments consisted of the months that data were collected, and plants were evaluated at intervals of 30 days at the initial growth phase, from December 2008 to June 2009, in a total of 7 months.

The experimental design was randomized blocks with four replications, totaling 28 plots. In the first month, 8 plants per plot were used in order to have enough material for chemical analysis, and in the other, three plants per plot were used.

Every 30 days, plants were removed from the greenhouse and taken to the laboratory for sample preparation, where development evaluations were performed. Leaves, rhizomes and roots were separated and washed with water and distilled water. The same procedure was performed for inflorescences harvested when they reached the optimum point for harvest, throughout the experimental period. The parameters related to growth and development of different parts of calla lily plants were:

- Plant: height, total leaves number, diameter and length of newly mature leaves, diameter, rhizome diameter and length.

- Buds: number of side buds, height, number of leaves and diameter of the most developed bud.

- Dry mass: for dry mass determination, the material was placed in Kraft-type paper bags and dried in an oven with forced air at a temperature from $65^{\circ} \mathrm{C}$ to $70^{\circ} \mathrm{C}$ up to constant weight. The dry mass of shoots, rhizomes, roots and flower stalks and total dry mass were analyzed, being obtained by the sum of the dry mass of each plant at each assessment time.

- Yield: inflorescences were evaluated as for quality, considering the spathe width and length, length and diameter of the flower stalk and the fresh mass corresponding to the harvest time. To assess the dry mass and number of flower stalks, the data accumulated by plant corresponding to the month throughout the study period were used.

Data were submitted to analysis of variance and the significant $\mathrm{F}$ test results $(\mathrm{P}<0.05)$ were submitted to polynomial regression analysis using the System of Analysis of Variance for Balanced Data software (Sisvar) (FERREIRA, 2007).

\section{RESULTSAND DISCUSSION}

Throughout the experimental period, plants showed satisfactory development, probably favored by the substrate and doses of nutrients used, which were suitable, since constant growth and no symptoms of deficiency were observed. When analyzing the characteristics related to growth during 7 months of evaluation, significant effects for all variables were observed.

The plant height increased on average $6.36 \mathrm{~cm}$ every 30 days, totaling $91.46 \mathrm{~cm}$ at 210 days (Figure 1). The final value differs from the observations of Almeida (2007) and Souza (2010), who observed in calla lily cultivation in nutrient solution, average heights of 44.57 $\mathrm{cm}$ at 210 days and $17.88 \mathrm{~cm}$ after 360 days, respectively. This difference can be attributed to the different origin of plants that gave origin to explants for micropropagation of seedlings. 


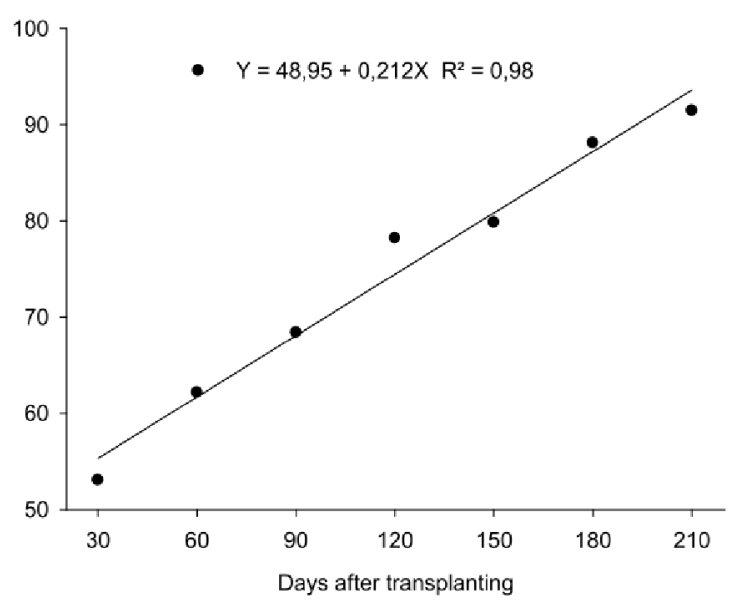

Figure 1 - Average calla lily plant height in function of days after transplanting.

Analyzing the plant stem diameter, there was an average increase of $0.34 \mathrm{~cm}$ every 30 days, reaching 4.17 $\mathrm{cm}$ at 210 days (Figure 2). It is essential that the stem diameter follows plant growth, mainly of shoots, supporting its weight and avoiding the falling of calla lily plants. By verifying that the height growth occurred concomitantly with the increase in stem diameter of the plant, it can be inferred that there was no etiolation of the shoot. Moreover, this parameter has been considered as an important indicator reflecting the plant quality (SCALON et al., 2002).

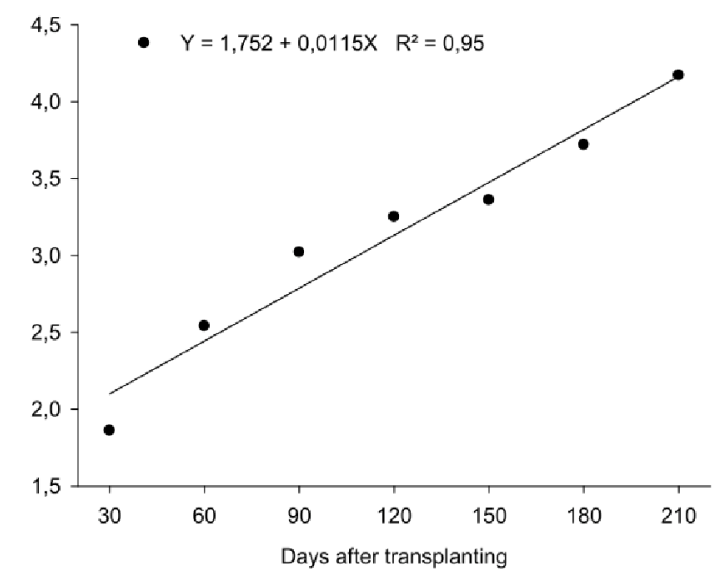

Figure 2 - Stem diameter of calla lily plants in function of days after transplanting.

The total production of leaves followed the increase of plant height, with concomitant constant increasing (Figura 3). At 210 days, the plants had, on average, 41.58 leaves compared with 59.75 leaves per plant obtained by Almeida (2007) after 360 days of calla lily cultivation also in nutrient solution. Considering the difference between the cultivation periods analyzed, the values are quite close.

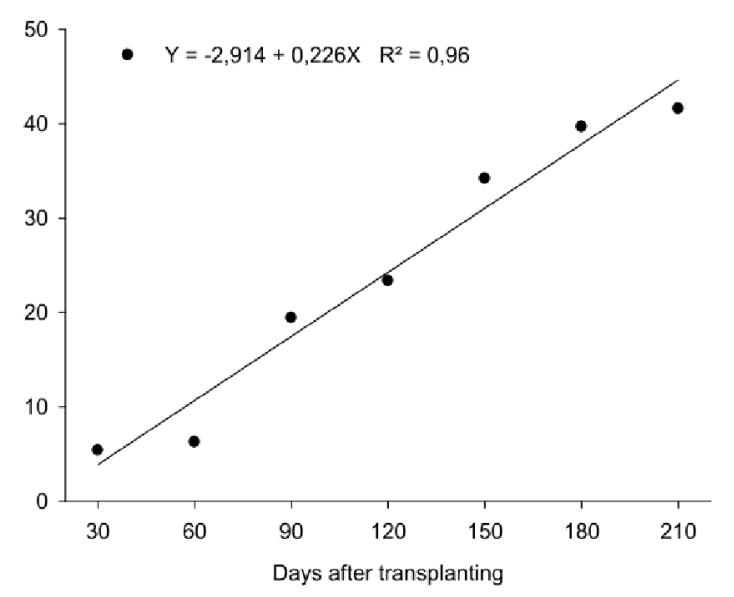

Figure 3 - Total number of leaves of calla lily plants in function of days after transplanting.

The leaf growth was accelerated, stabilizing after 90 days (Figure 4). At 159 days, leaves showed the highest length, $29.13 \mathrm{~cm}$, with the largest width, $22.50 \mathrm{~cm}$, observed at 139 days. At 210 days, the dimensions observed were 20.99 and $27.91 \mathrm{~cm}$ for leaf width and length, respectively, which are similar to those observed by Souza (2010) of 24.77 $\mathrm{cm}$ and $29.10 \mathrm{~cm}$, respectively, after 210 days of cultivation in nutrient solution. However, under these same culture conditions, Almeida (2007) observed average leaf width and length of $11.25 \mathrm{~cm}$ and $16.78 \mathrm{~cm}$, respectively at 12 months.

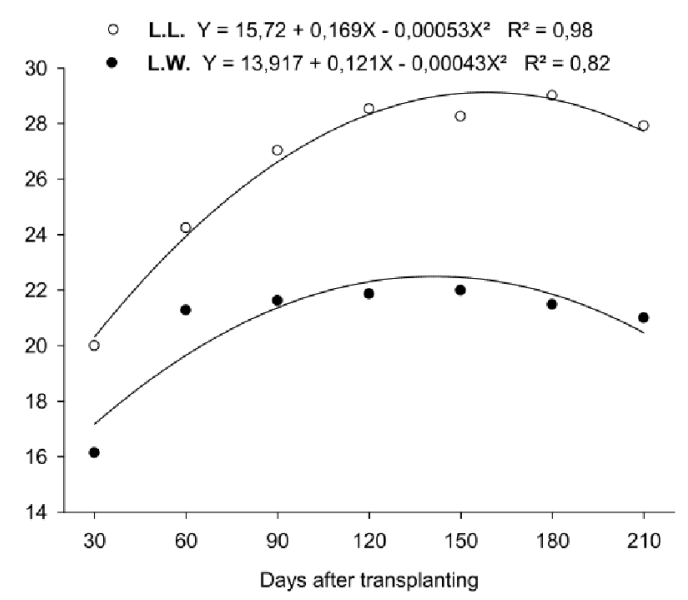

Figure 4 - Leaf length (LL) and width (LW) of calla lily plants in function of days after transplanting. 
The number of buds also showed increase proportional with cultivation time, being produced on average 4.4 buds per plant every 30 days, reaching an average of 29.30 buds per plant at 210 days (Figure 5). In an experiment conducted in nutrient solution by Almeida (2007), there was an average production of 13.6 buds per plant, indicating that the fertilization doses used did not favor the plant sprouting.

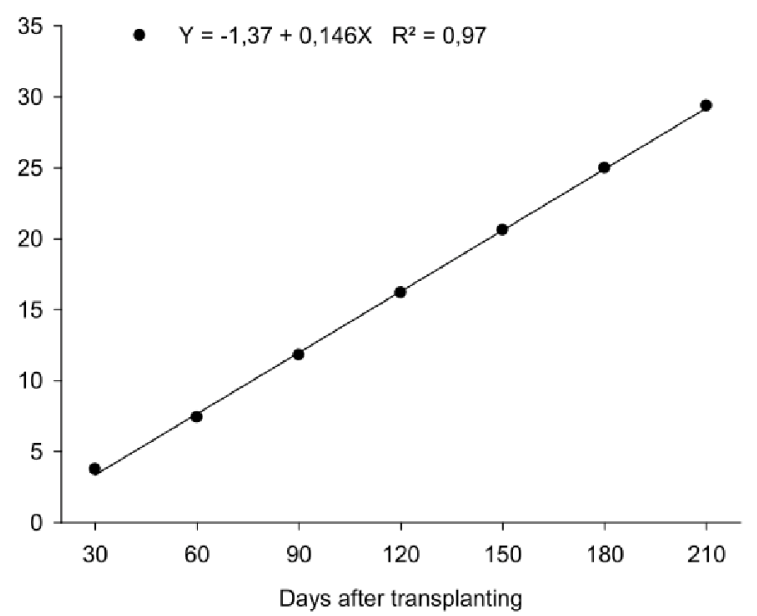

Figure 5 - Number of buds formed in calla lily plants in function of days after transplanting.

There was a positive relationship between plant height, number of leaves, and number of buds produced suggesting that, regardless of mother plant growth, reserves are aimed at the growth of new sprouts.

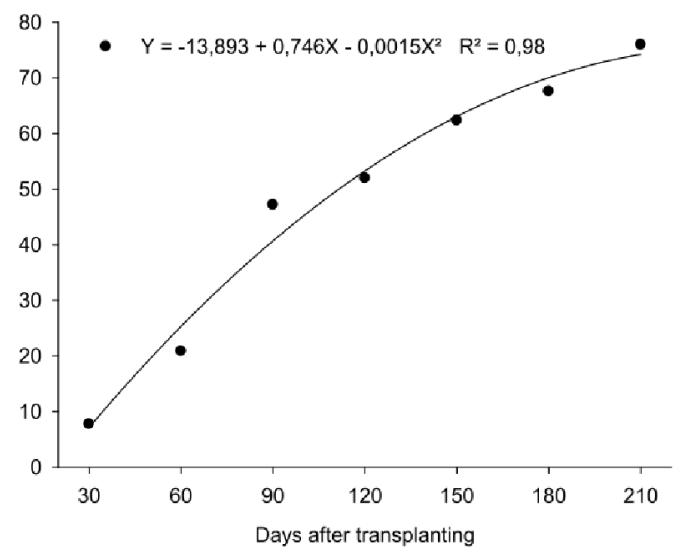

The height of the largest bud (Figure 6) also increased over the culture days, reaching $75.98 \mathrm{~cm}$ after 210 days. In calla lily shoots, the production of flower stalks does not only occur on the mother plant, as from the moment that the buds have the same developmental characteristics as the mother plant, they acquire the flowering ability (ALMEIDA; PAIVA, 2005). It should be observed that the size of the buds at 210 days corresponded to the size of the mother plant at 128 days; however, the buds showed a flowering ability from 150 days after transplanting, when they reached about $62 \mathrm{~cm}$ in height.

The number and height of buds produced are important variables, since the division of shoots and rhizomes is the primary method of propagation of this species (ALMEIDA, PAIVA, 2005, TAVARES et al., 2005). Higher number of leaves, 5 per bud (considering the largest bud) were obtained at 180 days, tending to stabilize after this period (Figure 6). Whereas producers individualize seedlings with 2-3 leaves (ALMEIDA; PAIVA, 2005) under the experimental conditions, the buds showed this pattern after 68 days of cultivation, with an average height of $36.7 \mathrm{~cm}$.

Rhizomes grew steadily over the assessment months, reaching (Figure 7), a length of $5.72 \mathrm{~cm}$ and diameter of $4.3 \mathrm{~cm}$ after 210 days. The growing size of the rhizome reflects the plant growth and production, since the higher the weight of rhizomes, the greater the amount of reserves that it will have to issue new shoots and buds (SOARES et al. 2005; TAVARES et al., 2007).

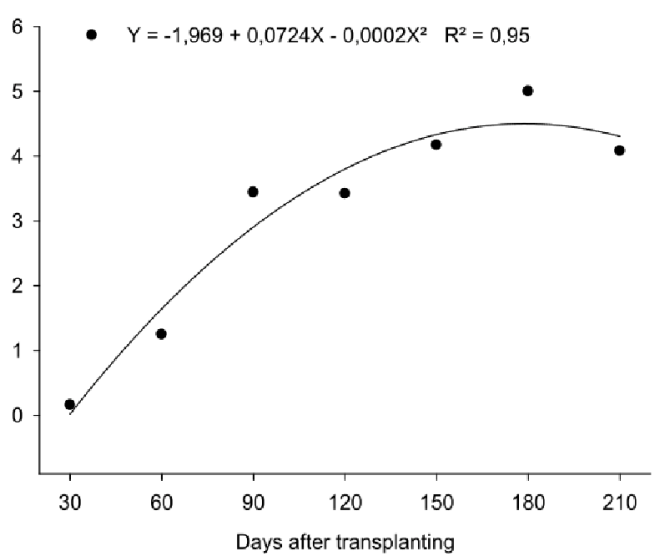

Figure 6 - Height of the largest bud (left) and number of leaves in the largest bud (right) in calla lily seedlings grown in nutrient solution in function of days after transplanting.

Ciênc. agrotec., Lavras, v. 35, n. 6, p. 1085-1092, nov./dez., 2011 


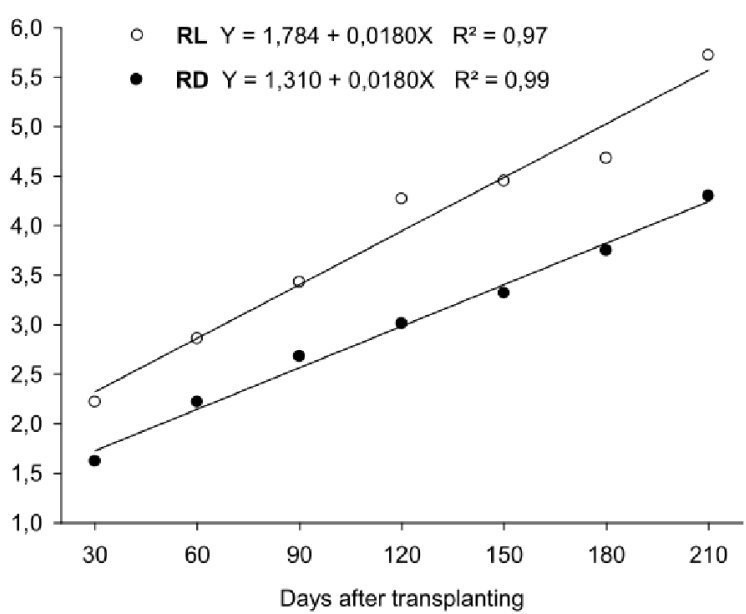

Figure 7 - Rhizome length (RL) and diameter (RD) in calla lily plants in function of days after transplanting.

It is common to observe a reduction in the amount of dry mass at the end of plant cycle; however, the dry mass accumulation under the conditions in which the experiment was conducted, despite increasing during the study period, did not reach maximum leaves. This fact can be explained by the evaluation period, which included only the initial development phase. The highest total dry mass production was observed at 210 days, on average $131.71 \mathrm{~g} \mathrm{plant}^{-1}$ (Figure 8). The dry mass accumulated in the plants was higher compared to that reported by Souza (2010) which, at 210 days after transplantation, obtained an average of 29.6 g plant $^{-1}$. The highest accumulation rate occurred in the period between 180 and 210 days, when the increment observed was $1.24 \mathrm{~g} \mathrm{day}^{-1}$.

Figure 8 shows that after 120 days, there was a significant increase in dry mass accumulation in rhizomes. Table 1 shows that, after 210 days, the greatest amount of dry matter accumulation in the plant was in shoots and rhizomes, $35.33 \%$ and $32.0 \%$ respectively, and the remaining in roots $(18.83 \%)$ and flower stalks $(13.9 \%)$.

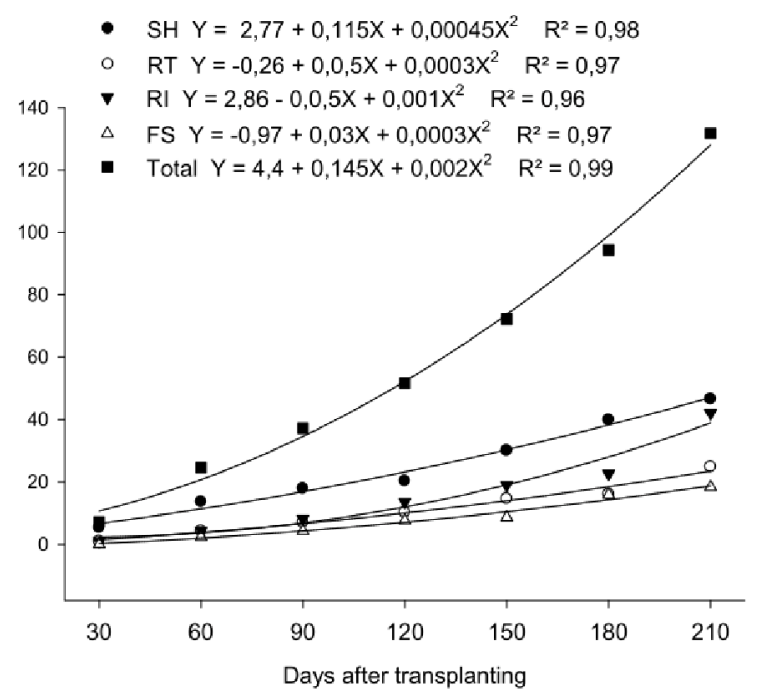

Figure 8 - Dry mass production in shoots ( $\mathrm{SH})$, roots (RT), rhizome (RI), flower stalk (FS) and total (Total) of calla lily plants in function of days after transplanting.

The proportional dry matter accumulation between shoots and rhizomes was reversed: while a reduction was observed the shoots over time, rhizomes showed increased dry mass accumulation. Throughout the study period, the plant applied its reserves for the production of flower stems, roots and mainly for growth and dry mass accumulation of the rhizome. At the beginning of the vegetative growth, leaves are preferred over organs to allocate biomass, and with plant growth, reserves are accumulated in the rhizome (SOARES et al., 2005).

Table 1 - Percentage of dry matter accumulation (DM) in shoots, roots, rhizomes and flower stalks of calla lily plants and total dry mass in function of the different sampling times.

\begin{tabular}{cccccc}
\hline \multirow{2}{*}{ Days } & TOTAL DM & SHOOTS & ROOT & RHIZOME & FLOWER STALK \\
\cline { 3 - 6 } & $(\mathrm{g})$ & 73.44 & 12.92 & 13.8 & 0.0 \\
\hline 30 & 7.20 & 55.47 & 17.36 & 17.5 & 9.6 \\
60 & 24.60 & 48.05 & 18.82 & 21.8 & 11.4 \\
90 & 37.20 & 39.30 & 19.74 & 26.3 & 14.7 \\
120 & 51.67 & 41.61 & 20.23 & 26.2 & 11.9 \\
150 & 72.17 & 42.26 & 16.96 & 24.0 & 16.8 \\
180 & 94.36 & 35.33 & 18.83 & 32.0 & 13.9 \\
210 & 131.71 & & & & \\
\hline
\end{tabular}


The period of greatest dry matter accumulation in shoots occurred in the first months after transplantation, possibly due to the need to increase the leaf surface. According to Urchei et al. (2000), at the beginning of plant growth, most of the photosynthesized material is converted into leaves for greater uptake of solar radiation, but with phenological development, the production is also aimed at non-assimilatory structures such as bulbs and roots.

Plants began flowering 30 days after transplanting. Analyzing the average number of flowers per plant, no significant difference between the evaluation months was observed; however, plants bloom more than once over the study period (Table 2). Souza (2010), growing calla lily in nutrient solution, obtained the issue of 1.24 flower stalks, on average, per plant, within a period of 210 days and Almeida (2007) observed the average issue of 3 stalks per plant over a period of 12 months. However, despite the higher production of flower stalks, the issue of only 2.67 flower stalks per plant was observed.

Table 2 - Average number of flower stalks per calla lily plant at intervals and accumulated, in function of the different sampling times.

\begin{tabular}{ccc}
\hline Days & $\begin{array}{c}\text { Number of flower } \\
\text { stalks / plant }\end{array}$ & $\begin{array}{c}\text { Average number of } \\
\text { total }\end{array}$ \\
\hline 30 & 0 & 0 \\
60 & 0.83 & 0.83 \\
90 & 0.42 & 1.08 \\
120 & 0.67 & 1.67 \\
150 & 0.42 & 1.42 \\
180 & 0.75 & 2.33 \\
210 & 0.58 & 2.67 \\
\hline
\end{tabular}

Plant age is another factor that influences flowering. Considering that calla lily is a perennial plant, they were still at the early cultivation stage and not physiologically able to reach the productive potential of flower stalks. Moreover, climatic factors should also be considered, because during the last evaluation months, plants grew under milder temperatures, conditions necessary for flowering in calla lily (ALMEIDA; PAIVA, 2005).

The length and width of the spathes formed also increased with cultivation time (Figure 9). At 210 days, spathes had $16.55 \mathrm{~cm}$ in length and $14.92 \mathrm{~cm}$ in width, on average, featuring large-size flowers and with excellent market potential, although there is no defined quality standard for the marketing of this species (ALMEIDA et al., 2008; ALMEIDA et al., 2009). Souza (2010), growing calla lily in nutrient solution showed that, after 210 days, the spathe had $14.53 \mathrm{~cm}$ in length and $11.68 \mathrm{~cm}$ in width, on average. Under the same culture conditions, Almeida (2007) observed $9.79 \mathrm{~cm}$ and $9.35 \mathrm{~cm}$ for spathe length and width, respectively, at the end of a cultivation period of 12 months.

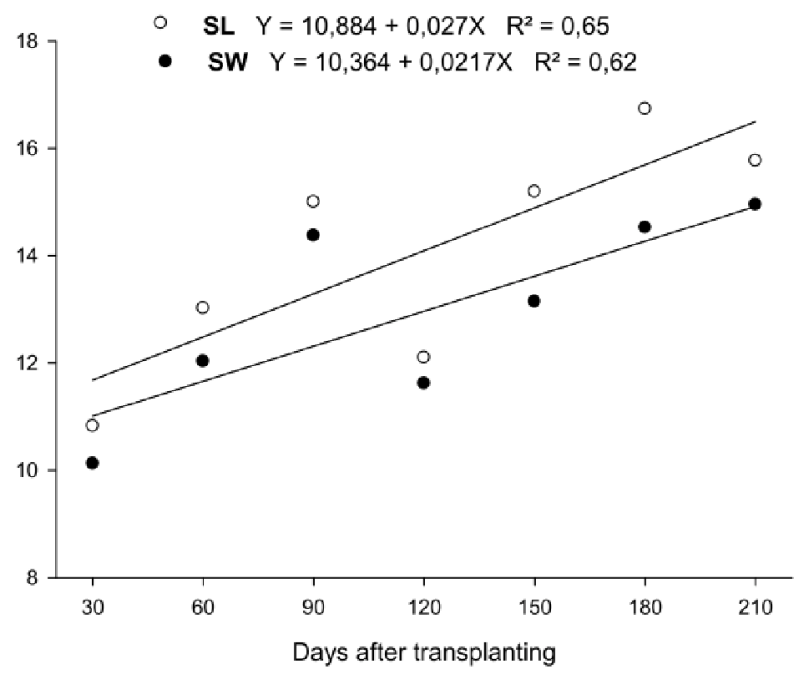

Figure 9 - Spathe length (SL) and width (SW) of calla lily plants related to days after transplanting.

The average length and diameter of flower stalks also showed constant increase. At 210 days, flower stalks had on average $80.7 \mathrm{~cm}$ in length and $1.35 \mathrm{~cm}$ in diameter (Figure 10). The market requires flower stalks longer than $60 \mathrm{~cm}$; thus, after 100 days of planting, it is possible to produce calla lily stalks appropriate for marketing.

Typically, young calla lily plants produce small flowers, short stems and with small diameter, which are features that can be increased over time (Figure 9 and 10). Comparatively, Souza (2010) grew calla lily in nutrient solution and at 210 days and found similar stalk length and diameter values of $66.86 \mathrm{~cm}$ and $1.42 \mathrm{~cm}$, respectively. Under the same culture conditions, Almeida (2007) found $21.24 \mathrm{~cm}$ and $0.83 \mathrm{~cm}$, on average, for stalk length and diameter.

A constant increase in the fresh mass of flower stalks was observed, corresponding to the number of days after planting. At 210 days, $102.76 \mathrm{~g} /$ flower stalk, with an increment of $15.60 \mathrm{~g}$ on average per month (Figure 11) was recorded. The largest fresh mass accumulation of flower stalks at 210 days corresponds to the period in which greater dry mass accumulation, length of flower stalks and larger spathes were found. 

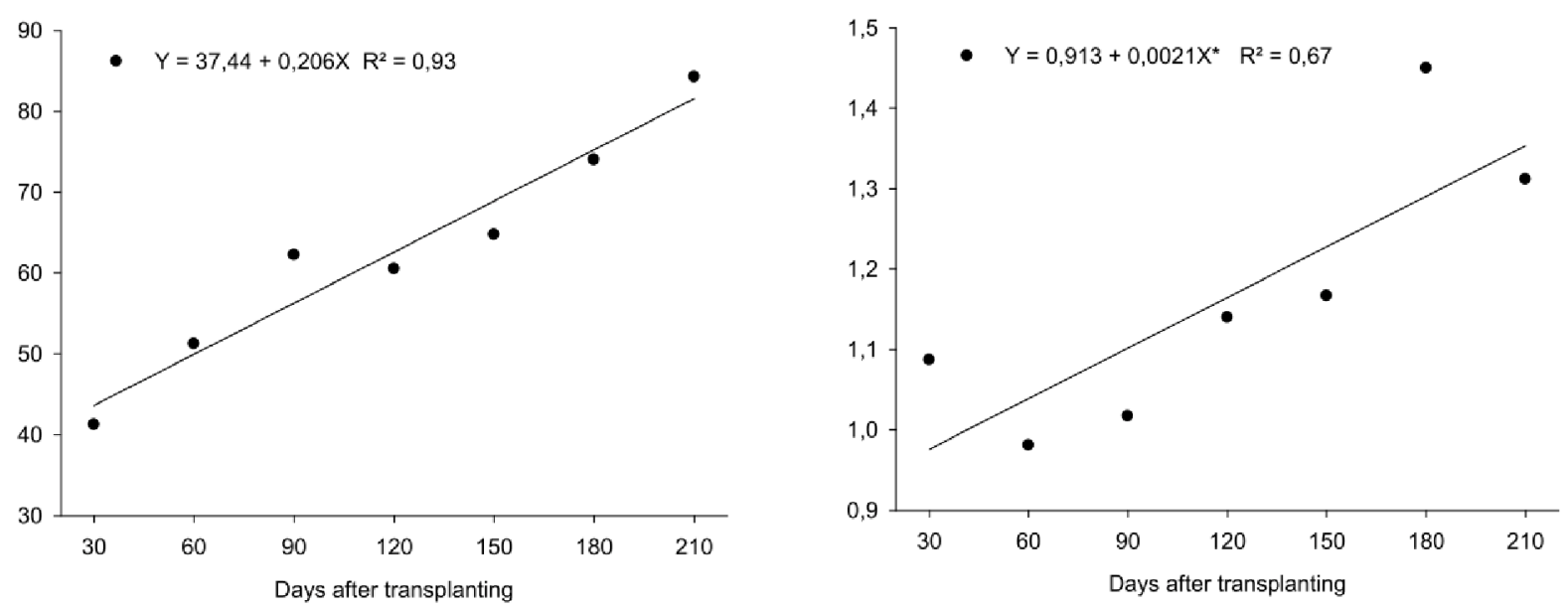

Figure 10 - Flower stalk length (A) and diameter (B) of calla lily plants related to days after transplanting.

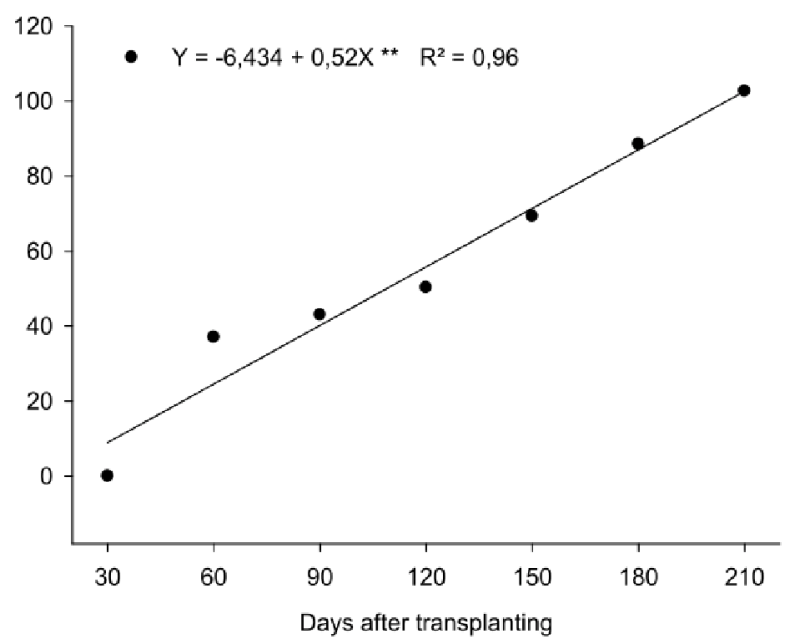

Figure 11 - Fresh mass of flower stalks of calla lily plants related to days after transplanting.

\section{CONCLUSIONS}

Calla lily plants grew steadily up until 210 days of cultivation.

The production of leaves increased up to 210 days of cultivation, as well as its dimensions, up to 90 days, stabilizing after this period.

The production of flower stalks with commercial standard occurred after 80 days.

At 210 days, the dry mass accumulation was higher in shoots and rhizomes, followed by roots and stalks.

\section{ACKNOWLEDGMENTS}

The authors would like to thank FAPEMIG for the financial support, and CAPES, CNPq and FAPEMIG for providing scholarships.

\section{REFERENCES}

ALMEIDA, E.F.A. Nutrição mineral em plantas de copode-leite: deficiência de nutrientes e adubação silicatada. 2007. 109 p. Tese (Doutorado em Fitotecnia) Universidade Federal de Lavras, Lavras.

ALMEIDA, E.F.A.; PAIVA, P.D.O. Cultivo de copode-leite. Informe Agropecuário, v.26, n.227, p.30-35, 2005.

ALMEIDA, E.F.A. et al. Pós-colheita de copo-de-leite: efeito de diferentes conservantes comerciais e armazenamento a frio. Ciência e Agrotecnologia, v.32, p.4-1194, 2008.

ALMEIDA, E.F.A. et al. Senescência de inflorescências de copo-de-leite: influência de diferentes armazenamentos e procedimentos pós-colheita. Revista Brasileira de Horticultura Ornamental, v. 15, p. 71-76, 2009.

CABRERA, R.I. Rose yield, dry matter partitioning and nutrient status responses to rootstock selection. Scientia Horticulturae, v. 95, n.1/2, p. 7583, 2002. 
DUFOUR, L.; GUÉRIN, V. Nutrient solution effects on the development and yield of Anthurium andreanum Lind. in tropical soilless conditions. Scientia Horticulturae, v.105, n.2, p.269-282, 2005.

FERREIRA, D.F. SISVAR-sistema de análise de variância: versão 5.0. Lavras: UFLA, 2007.

LANDGRAF, P.R.C.; PAIVA, P.D.O. Agronegócio da floricultura brasileira. Magistra, v.21, p.253-261, 2009a.

LANDGRAF, P.R.C.; PAIVA, P.D.O. Produção de flores cortadas no Estado de Minas Gerais. Ciência e Agrotecnologia, v.33, n.1, p.120-126, 2009b.

MALAVOLTA, E. Manual de nutrição mineral de plantas. São Paulo: Agronômica Ceres, 2006. 638 p.

MALAVOLTA, E.; MURAOKA, T. Avaliação do estado nutricional e da fertilidade do solo: métodos de vegetação e diagnose por subtração em vasos. Piracicaba: CENA/USP, 1985. 7 p. Mimeografado.

ORTEGA, B.R.; CORREA, B.M.; OLATC, M.E. Determinación de las curvas de acumulación de nutrientes en tres cultivares de Lilium spp para flor de corte. Agrociência, v. 40, p. 77-88, 2006.

PEDROSA, M.W. Concentração e acúmulo de nutrientes em plantas de Gypsophila paniculata L. cultivadas em solução nutritiva. Revista Brasileira Horticultura Ornamental, Campinas, v.6, n.1/2, p.1930,2000 .
SCALON, S.P.U; MUSSURY R.M.; RIGONI, M.R. Crescimento inicial de mudas de espécies florestais nativas sob diferentes níveis de sombreamento. Revista Árvore, v.26, n.1, p.1-5, 2002.

SOARES, F.A.L. et al. Partição de fotoassimilados em cultivares de bananeira irrigadas com águas de diferentes salinidades. Revista Brasileira de Engenharia Agrícola e Ambiental, v.9 (Suplemento), p.101-107, 2005.

SOUZA, R.R. et al. Doses de boro no desenvolvimento de copo-de-leite em solução nutritiva. Ciência e Agrotecnologia, v.34, n.6, p.1396-1403, 2010.

TAVARES, T.S. et al. Desenvolvimento de mudas de copo-de-leite submetidas ao pré-tratamento com ácido giberélico e cultivadas em diferentes substratos. Revista Brasileira de Horticultura Ornamental, v.11, n.2, p.127131,2005.

URCHEI, M.A.; RODRIGUES, J.D.; STONE, L.F. Análise de crescimento de duas variedades de feijoeiro sob irrigação, em plantio direto e preparo convencional. Pesquisa Agropecuária Brasileira, v.35, n.3, p.497-506, 2000.

VARGAS, P.A.; TEJOS, D.P. Producción de materia seca y absorción de nitrógeno del cultivo de tulipán (Tulipa gesneriana L.). Agrociencia, v.42, p.37-45, 2008.

VIEIRA, N.M.B. et al. Altura de planta e acúmulo de matéria seca do feijoeiro cvs. BRS MG Talismã e Ouro Negro em plantio direto e convencional. Ciência e Agrotecnologia, v.32, p.1687-1693, 2008. 